\title{
Infection of Barley by Brome Mosaic Virus Is Restricted Predominantly to Cells in and Associated with Veins through a Temperature-Dependent Mechanism
}

\author{
Xin Shun Ding, ${ }^{1}$ Stanislaw Flasinski, ${ }^{2}$ and Richard S. Nelson ${ }^{1}$ \\ ${ }^{1}$ The Samuel Roberts Noble Foundation, Plant Biology Division, P.O. Box 2180, Ardmore, OK 73402, \\ U.S.A.; ${ }^{2}$ Monsanto, 700 Chesterfield Parkway North, St. Louis, MO 63198, U.S.A. \\ Accepted 7 April 1999.
}

\begin{abstract}
Results from previous cytological studies on barley (Hordeum vulgare) infected with brome mosaic virus (BMV) indicated that this virus can infect and accumulate to high levels in mesophyll and other cell types within the leaves. Through immunocytochemistry and in situ hybridization, we have determined that BMV infection in barley is restricted predominantly to cells within and associated with vasculature when plants are grown at $24 / 20^{\circ} \mathrm{C}$ (day/night). This tissue restriction can be fully overcome by growing infected plants at $34^{\circ} \mathrm{C}$ for $2 \mathrm{~h}$. Our results also indicate that BMV is likely to start systemic infection of young, uninoculated leaves in barley before spreading into all longitudinal veins in inoculated leaves. Possible barrier(s) to BMV movement between vascular bundle sheath cells and mesophyll cells, and the relationship between virus and photoassimilate transport through longitudinal and transverse veins are discussed.
\end{abstract}

Additional keywords: cell-to-cell movement, phloem, phloemdependent accumulation, plasmodesmata, temperature effect, vascular tissue.

Brome mosaic virus (BMV) has been identified in and isolated from plants growing in many parts of the world (Lane 1981 and references therein). It can infect several agronomically important members of the Poaceae family in nature, and several dicotyledonous species under laboratory conditions (Ford et al. 1970). Although BMV has been used extensively as a model virus to study virus replication, viral gene expression, and interactions between virus and host factors (e.g., Kaido et al. 1995; Kasteel et al. 1997; Loesch-Fries and Hall 1980; for review see Sullivan and Ahlquist 1997), a lesser effort has been made to investigate the cell-to-cell movement and phloem-dependent accumulation of the virus in infected monocotyledonous plants (e.g., Allison et al. 1988; Traynor et al. 1991).

BMV is a type member of the Bromovirus genus and can be transmitted efficiently by mechanical inoculation to host plants. The capsids of this virus are isometric and contain one single-stranded, positive-sense RNA1, RNA2, or RNA3 and subgenomic RNA4. RNAs 1 and 2 encode, respectively, the

Corresponding author: Xin Shun Ding; Telephone: 1-580-223-5810; Fax: 1-580-221-7380; E-mail: xsding@ noble.org 1a and 2a proteins that are necessary for BMV replication (Kiberstis et al. 1981; Kroner et al. 1989, 1990; Quadt and Jaspars 1990). RNA 3 encodes the 3 a protein that is required for the cell-to-cell movement of the virus in host plants (Ahlquist et al. 1981; Allison et al. 1988). Subgenomic RNA 4, expressed from the 3' end of RNA 3, encodes the capsid protein (CP) (Dasgupta and Kaesberg 1982). Work from several groups (De Jong et al. 1995; Flasinski et al. 1995; Rao and Grantham 1996; Traynor et al. 1991) has shown or suggested that the $2 \mathrm{a}$ protein, $3 \mathrm{a}$ protein, and CP are involved in systemic infection of the plants by the virus. In addition, the 3a protein gene and/or its encoded protein have been reported to play an important role in determining host range (Allison et al. 1988; De Jong et al. 1995; Mise and Ahlquist 1995; Mise et al. 1993; Osman et al. 1997).

Barley (Hordeum vulgare) is a natural host of BMV (McKinney 1953). Typical visual symptoms on infected barley plants are chlorotic streaks on the leaves and stunting of the plants. Cytopathological studies on barley leaves infected with BMV showed that numerous virus particles are present in epidermal, mesophyll (M), and various types of vein cells (Paliwal 1970) and in M protoplasts prepared from such tissue (Okuno and Furusawa 1978a, 1978b). BMV virions were also observed in the intercellular spaces between $M$ and bundle sheath (BS) cells in infected barley leaves (Paliwal 1970). In this study, we have investigated BMV accumulation over time in specific cells of both inoculated and systemically infected barley leaves of plants grown under specific light and temperature regimes through immunocytochemistry and in situ hybridization. We have determined that transient temperature fluctuation can dramatically affect BMV accumulation in specific cells of barley leaves over time.

\section{RESULTS}

Visual symptoms and CP accumulation in extracts.

The inoculated leaves of $H$. vulgare cvs. Morex, Post 40, and Tam Bar401 plants showed chlorotic streaks by 3 days post inoculation (dpi) when growth conditions were $24 / 20^{\circ} \mathrm{C}$ (day/night). Some of the streaks on the inoculated leaves became necrotic by 5 dpi (data not shown). Uninoculated, young leaves of the inoculated plants showed chlorotic streaks by 5 dpi followed by stunting of the infected plants. Similar symptoms were observed on the virus-inoculated plants grown at 
$26 / 20^{\circ} \mathrm{C}$. No virus symptoms were seen on mock-inoculated plants grown under the same conditions. For the inoculated leaves of Morex grown at $24 / 20^{\circ} \mathrm{C}, \mathrm{CP}$ of BMV was detected in $20 \%$ of the blades and $0 \%$ of the sheaths (proximal to the stem) analyzed at 2 dpi (Table 1). The accumulation of CP continued in the blade and appeared in the sheath by 3 dpi. All analyzed leaf blades and sheaths accumulated $\mathrm{CP}$ by 4 dpi (Table 1). The mean concentrations of BMV CP in infected blades and sheaths harvested at 4 dpi were approximately 80 and $26 \mu \mathrm{g}$ per $\mathrm{mg}$ of total protein, respectively.

\section{Immunocytochemical detection of cell-specific BMV accumulation.}

At 2, 3, 4, and $8 \mathrm{dpi}$, inoculated leaves from Morex grown at $24 / 20^{\circ} \mathrm{C}$ were sectioned and analyzed for the accumulation of BMV CP by immunocytochemistry and light microscopy. A randomly chosen section, basipetal to the inoculation site, from each sampled leaf was examined under the light microscope for virus accumulation in different cells. In total, 374 longitudinal veins (22 midribs, 103 large, 187 intermediate, and 62 small veins) in 38 sections were examined. The large veins were characterized by the presence of a protoxylem lacuna and two large metaxylem vessels. In agreement with other reports, the intermediate and small veins lacked the large metaxylem vessels and were similar in structure to each other, except the small veins were not associated with hypodermal sclerenchyma cells (data not shown; Botha and Cross 1997; Dannenhoffer et al. 1990). At 2, 3, 4, and 8 dpi, respectively, BMV was present in approximately 10, 40, 90, and $100 \%$ of the analyzed sections. In infected sections from the inoculated leaf blades, BMV CP was present in approximately 14 (2 dpi), 27 (3 dpi), 22 (4 dpi), and 73\% (8 dpi) of the analyzed veins. The percentage of infected midrib and large veins was higher than that observed for the intermediate and small veins (Table 2). In all sections examined, BMV was not detected in M cells except in those adjacent to BS cells of the infected veins (Fig. 1A). When paradermal sections from the inoculated Morex leaf blades were analyzed, BMV CP again was detected predominantly in cells within and adjacent to longitudinal and transverse veins (Fig. 2). Similar results were obtained when sections from four inoculated Morex leaf blades were analyzed by immunocytochemistry and electron microscopy (e.g., Fig. 3). Analysis of sections from the inoculated leaf blades of Post 40 and Tam Bar401 plants harvested at 8 dpi gave results similar to those observed for the inoculated Morex leaves (data not shown). Within infected veins, the virus was detected mainly in BS, mestome sheath (MS), and vascular parenchyma (VP) or companion (C) cells (Fig. 1A). It was not

Table 1. Detection of brome mosaic virus (BMV) coat protein by enzyme-linked immunosorbent assay (ELISA) in blades and sheaths of the inoculated leaves from plants (Hordeum vulgare cv. Morex) harvested over time

\begin{tabular}{|c|c|c|c|c|}
\hline \multirow[b]{2}{*}{ Experiment } & \multirow[b]{2}{*}{ Tissue analyzed } & \multicolumn{3}{|c|}{ Days post inoculation } \\
\hline & & 2 & 3 & 4 \\
\hline \multirow[t]{2}{*}{1} & Blade & $1 / 5^{\mathrm{a}}$ & $2 / 5$ & $5 / 5$ \\
\hline & Sheath & $0 / 5$ & $1 / 5$ & $5 / 5$ \\
\hline \multirow[t]{2}{*}{2} & Blade & $1 / 5$ & $5 / 5$ & $5 / 5$ \\
\hline & Sheath & $0 / 5$ & $4 / 5$ & $5 / 5$ \\
\hline
\end{tabular}

${ }^{a}$ Number of tissues infected/number of tissues analyzed. possible to distinguish between VP and C cells in these sections. Occasionally, virus was detected in xylem vessels. Both chlorenchymatous and colorless cells associated with midribs also contained the virus (data not shown). When inoculated leaf blades from Morex plants grown at $26 / 20^{\circ} \mathrm{C}$ were sampled and analyzed at $8 \mathrm{dpi}$, most cells within vascular bundles were found to be infected. Similar to the results obtained with plants grown at $24 / 20^{\circ} \mathrm{C}$, the majority of $\mathrm{M}$ cells between veins (65 of 66 areas observed) did not contain detectable levels of BMV CP or BMV RNA. M cells that contained the virus were again adjacent to BS cells of the infected veins (Fig. $4 \mathrm{~A}$ and data not shown).

Since we did not observe many infected $M$ cells in the inoculated leaves, experiments were initiated to determine if BMV could accumulate in $\mathrm{M}$ cells in systemically infected Morex leaves. Leaf blades of infected plants grown at 24/20 or $26 / 20^{\circ} \mathrm{C}$ were sampled at $8 \mathrm{dpi}$ for immunocytochemical analysis. For infected plants grown at $24 / 20^{\circ} \mathrm{C}$, approximately $92 \%$ of the longitudinal veins (66 out of 72 veins) had accumulated the virus (e.g., Fig. 5A). In only one interveinal area over $80 \%$ of the $\mathrm{M}$ cells not associated with the vasculature (i.e., nonvascular-associated $\mathrm{M}$ cells) contained the virus (Table 3). Similar results were obtained when systemically infected leaves of Morex grown at $26 / 20^{\circ} \mathrm{C}$ were sampled and analyzed at 8 dpi (Fig. 4B, Table 3 ). When systemically infected leaves of Morex grown at $24 / 20^{\circ} \mathrm{C}$ were harvested and analyzed at $25 \mathrm{dpi}$, the virus was still predominantly observed in vein cells and adjacent $M$ cells, compared with $M$ cells not associated with veins (e.g., Fig. 5B and data not shown).

\section{Cell-specific viral RNA accumulation by in situ hybridization.}

Sections from both the inoculated and systemically infected leaves of Morex plants grown at $24 / 20^{\circ} \mathrm{C}$ were probed with a biotinylated RNA probe specific for the conserved 3' untranslated regions of the three BMV RNA components to determine the location of viral RNA. BMV RNA components were detected predominantly in BS, MS, and VP or C cells, but not in $\mathrm{M}$ cells (Fig. 6A). No labeling signal was observed in sections from mock-inoculated leaves (Fig. 6B). Thus, accumulation of BMV RNA, like BMV CP, is restricted predominantly to cells within or adjacent to veins when plants are grown at temperatures ranging from 20 to $24^{\circ} \mathrm{C}$.

\section{Structure of plasmodesmata at various cell interfaces.}

To determine whether the lack of infection of $\mathrm{M}$ cells correlated with structural differences in plasmodesmata (PD) at various cell interfaces, a survey was conducted analyzing PD at these interfaces in infected plants. PD between $\mathrm{M}$ cells, $\mathrm{M}$

Table 2. Brome mosaic virus (BMV) infection of various vein classes from inoculated Morex leaves over time

\begin{tabular}{lcccc}
\hline $\begin{array}{l}\text { Days } \\
\text { post inoculation }\end{array}$ & Midrib & $\begin{array}{c}\text { Large } \\
\text { vein }\end{array}$ & $\begin{array}{c}\text { Intermediate } \\
\text { vein }\end{array}$ & $\begin{array}{c}\text { Small } \\
\text { vein }\end{array}$ \\
\hline $2^{\mathrm{a}}$ & $0 / 1^{\mathrm{b}}$ & $0 / 3$ & $1 / 7$ & $1 / 3$ \\
$3^{\mathrm{a}}$ & $2 / 3$ & $4 / 11$ & $6 / 23$ & $0 / 8$ \\
$4^{\mathrm{a}}$ & $6 / 6$ & $6 / 25$ & $9 / 49$ & $0 / 14$ \\
$8^{\mathrm{c}}$ & $7 / 7$ & $18 / 20$ & $25 / 36$ & $8 / 16$ \\
\hline
\end{tabular}

a Ten sections from leaves of 10 different plants were analyzed.

${ }^{b}$ Number of veins infected/number of veins in infected sections.

${ }^{c}$ Eight sections from leaves of eight different plants were analyzed. 
and BS (M/BS) cells, BS and BS (BS/BS) cells, BS and MS (BS/MS) cells, and MS (MS/MS) cells appeared structurally similar to each other, but different from those between VP cells (Fig. 7). PD between M cells, M/BS cells, BS/BS cells, BS/MS cells, and MS/MS cells had constricted electronopaque structures, termed sphincters (Robinson-Beers and Evert 1991), at their neck region (e.g., Fig. 7A and B, arrows). The cytoplasmic sleeve between the two sphincters was electron-lucent. PD in cell walls between all of these cells appeared as clusters. In contrast, PD between VP cells had similar wall-to-wall diameters throughout their length (Fig. 7C). Tubular structures containing viruslike particles similar to those observed by Kasteel et al. (1997) in cowpea protoplasts infected with BMV were not observed within or adjacent to PD in walls between infected cells (data not shown).
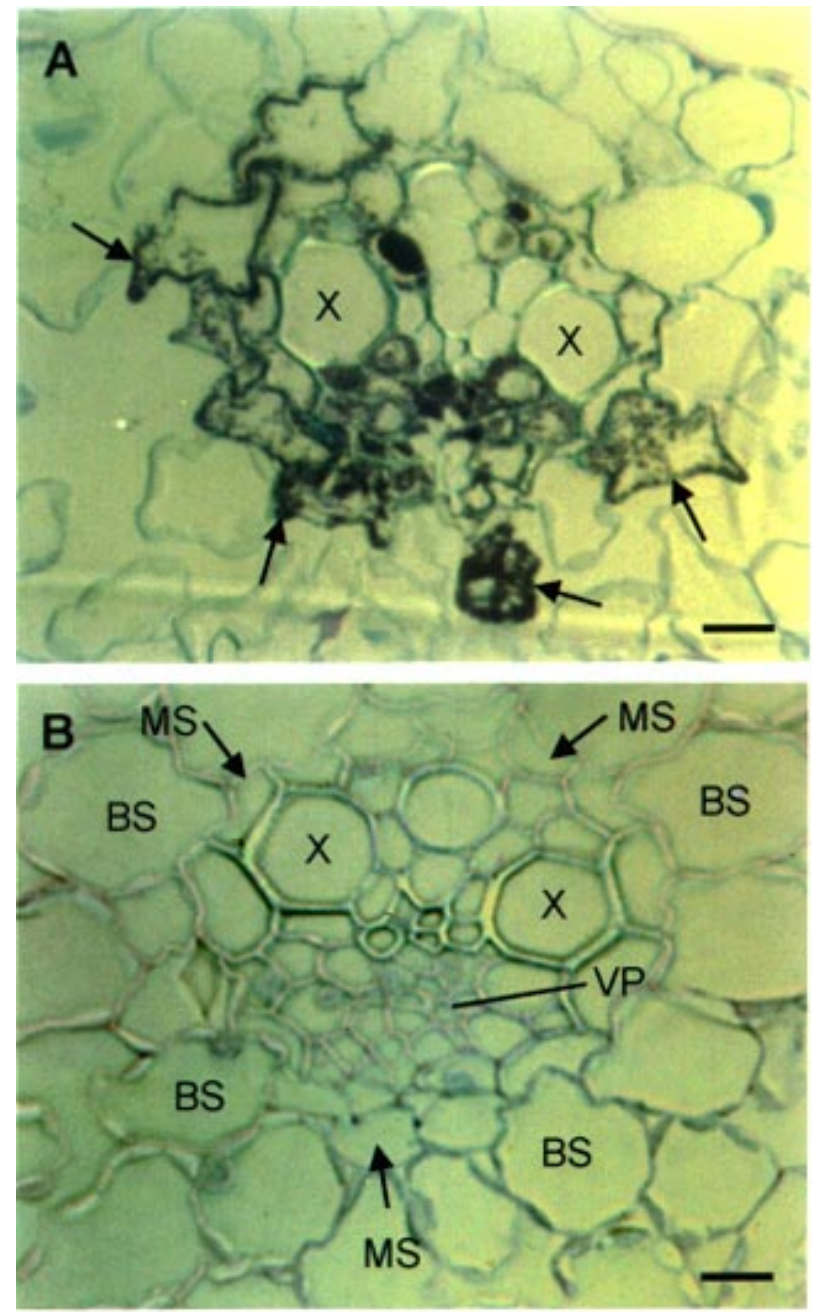

Fig. 1. Immunocytochemical detection of brome mosaic virus (BMV) capsid protein $(\mathrm{CP})$ in cells of a virus-inoculated leaf blade of Hordeum vulgare (cv. Morex) at 8 days post inoculation. A, Section from a large vein of a virus-inoculated leaf blade analyzed by immunocytochemistry with an antiserum against BMV CP followed by silver enhancement. Section was photographed under a Nikon Microphot-FX microscope as a Normarski image. Labeling signal appears as brown to black specks (examples noted by arrows). B, Section from a large vein of a mockinoculated leaf blade analyzed as for the section in A. BS, bundle sheath cell; MS, mestome sheath cell; VP, vascular parenchyma cell; X, metaxylem vessel. Bar $=12 \mu \mathrm{m}$.

\section{Effect of high temperature on BMV spread in barley leaves.}

When Morex was inoculated and grown at high temperatures $\left(34 / 32^{\circ} \mathrm{C}\right.$, day/night), both vein cells and $\mathrm{M}$ cells not associated with the vascular tissue in inoculated and systemically infected leaves accumulated BMV (data not shown). To determine if a transient high temperature treatment could also affect the cellular distribution of BMV in infected barley leaves, we placed BMV-infected plants at $34^{\circ} \mathrm{C}$ for 2,4 , or $8 \mathrm{~h}$ or at $30^{\circ} \mathrm{C}$ for $2 \mathrm{~h}$, and then at $24 / 20^{\circ} \mathrm{C}$ for an additional 3 days. Disease symptoms on virus-inoculated plants grown

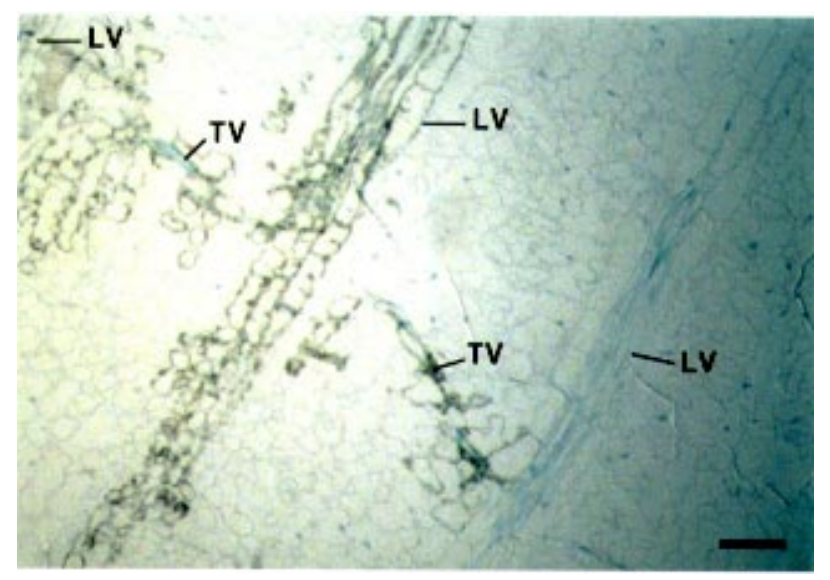

Fig. 2. Immunocytochemical detection of brome mosaic virus (BMV) capsid protein (CP) in cells of a virus-inoculated leaf blade of Hordeum vulgare (cv. Morex) at 8 days post inoculation. Micrograph is of a paradermal section analyzed for BMV CP accumulation as described in Figure 1. Labeling signal appears as brown specks. LV, longitudinal veins; $\mathrm{TV}$, transverse veins. $\mathrm{Bar}=38 \mu \mathrm{m}$.

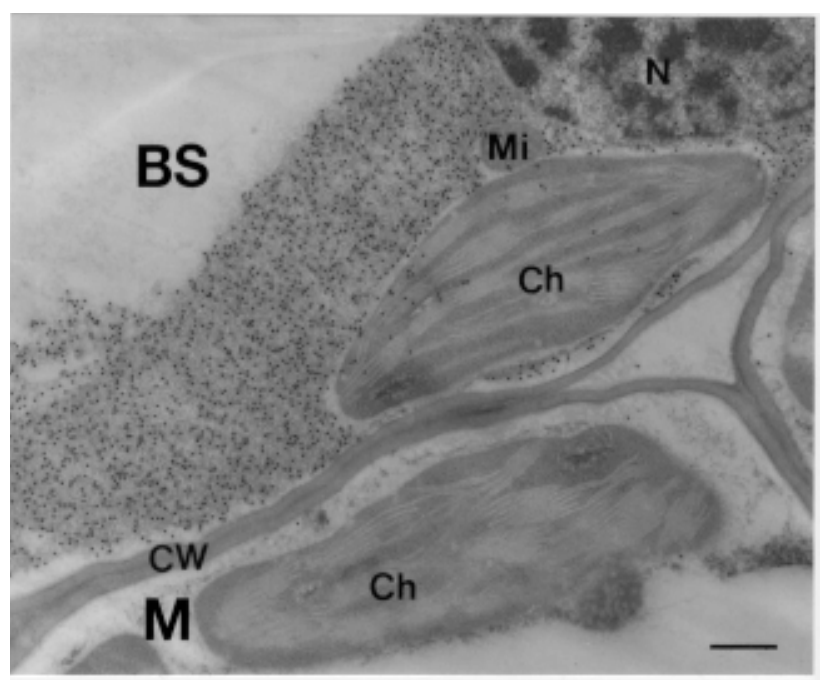

Fig. 3. Accumulation of brome mosaic virus (BMV) capsid protein (CP) in cells of a virus-inoculated blade of Hordeum vulgare (cv. Morex) at 8 days post inoculation. Accumulation of BMV CP was analyzed by immunocytochemistry with an antiserum against BMV CP and a goat antirabbit IgG gold $(20 \mathrm{~nm})$ conjugate. Section was photographed under an electron microscope. Immunogold particles can be seen in the cytoplasm of an infected bundle sheath cell, but not in the adjacent mesophyll cell. BS, bundle sheath cell; $\mathrm{Ch}$, chloroplast; $\mathrm{CW}$, cell wall; $\mathrm{M}$, mesophyll cell; $\mathrm{Mi}$, mitochondrion; $\mathrm{N}$, nucleus. $\mathrm{Bar}=0.8 \mu \mathrm{m}$. 
transiently at 34 or $30^{\circ} \mathrm{C}$ were similar to those described for virus-inoculated plants grown at $24 / 20^{\circ} \mathrm{C}$ (data not shown). However, when systemic leaves from inoculated plants exposed transiently to $34^{\circ} \mathrm{C}$ were sampled and analyzed by immunocytochemistry and light microscopy, high levels of BMV $\mathrm{CP}$ were detected in most vein and $\mathrm{M}$ cells (Table 3 and Fig. 8A). Similar results were obtained when the sections were probed for viral RNA accumulation by in situ hybridization (Fig. 8B). Tissues sampled from plants transiently exposed to $30^{\circ} \mathrm{C}$, however, accumulated virus in very few $\mathrm{M}$ cells not associated with vascular tissue (Table 3 and Fig. 8C). In all experiments, viral CP or RNA was not observed in sections from mock-inoculated leaves (Fig. 8D and data not shown). In tissue samples of infected control plants grown at $24 / 20^{\circ} \mathrm{C}$ exclusively, BMV infection was again localized mainly in vein cells (Fig. 8E).

\section{DISCUSSION}

For several decades it has been assumed that BMV can accumulate in all types of cells in infected barley leaves. This is because numerous BMV particles were observed by electron microscopy in different cell types, including $M$ cells, in infected leaves of barley (cv. Vantage) grown in a greenhouse at reported temperatures of 20 to $26^{\circ} \mathrm{C}$ (Paliwal 1970). Additionally, BMV virions and RNAs were detected in inoculated barley M protoplasts (Kiberstis et al. 1981; Loesch-Fries and Hall 1980; Okuno and Furusawa 1978b). Results from our work show that, at day/night temperatures of $24 / 20^{\circ} \mathrm{C}$ for all three cultivars tested, or at $26 / 20^{\circ} \mathrm{C}$ for Morex, BMV infection in barley was restricted predominantly to BS cells, vein cells, and a few $M$ cells associated with the veins in both inoculated and systemically infected leaves (Figs. 1A, 4A and B, and 5A, Table 3). Even at $25 \mathrm{dpi}$, the virus was unable to invade and accumulate in most $\mathrm{M}$ cells in systemically infected leaves (Fig. 5B). Therefore, we conclude that BMV infection in barley is restricted predominantly to vascular bundles under specific conditions. Because barley is a cool season crop, this tissue restriction may occur in production fields. Whether BMV infections in other monocotyledonous plants are also restricted
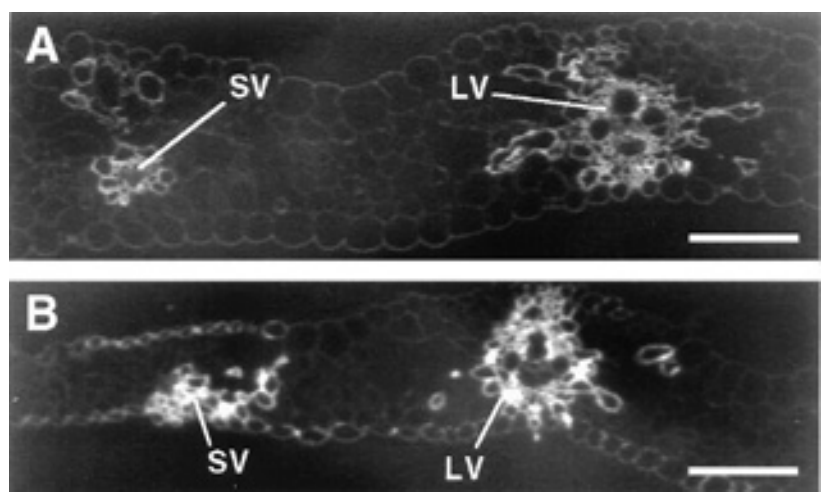

Fig. 4. Immunocytochemical detection of brome mosaic virus (BMV) capsid protein (CP) in cells of infected leaf blades of Hordeum vulgare (cv. Morex) grown at $26 / 20^{\circ} \mathrm{C}$. A, Section from an inoculated leaf blade harvested at 8 days post inoculation (dpi). B, Section from a systemically infected leaf blade harvested at 8 dpi. Both sections were analyzed for BMV CP accumulation as described in Figure 1 and photographed as dark field images. Arrows indicate cells displaying labeling signal. LV, large vein; SV, small vein. $\mathrm{Bar}=80 \mu \mathrm{m}$. predominantly to the vasculature at these temperatures has yet to be determined.

Considering this restriction of BMV invasiveness in barley at $24 / 20^{\circ} \mathrm{C}$, the question arises as to how this virus reaches vascular tissue after inoculation. It has been shown that large veins of barley leaves project above the interveinal adaxial leaf surface, and colorless cells resembling BS extensions extend between BS and hypodermal sclerenchyma (HS) cells (Trivett and Evert 1998). Since BMV can be readily detected in epidermal and colorless cells in tissues taken from virusinoculation sites (data not shown), it is possible that the virus establishes its initial infection in mechanically wounded HS cells and spreads into vascular bundles through colorless cells. Further studies will verify the validity of this model.

To date, only a few reports have been published on virus movement between and accumulation in $\mathrm{M}$ and BS cells in monocotyledonous and dicotyledonous plants (for review see Nelson and van Bel 1998). In regard to entry of viruses into veins, strains of tobacco mosaic virus (TMV) were not inhibited in accumulation in $\mathrm{M}$ cells and BS cells, although they differed in their ability to accumulate in internal vein cells of Nicotiana tabacum (Ding et al. 1995, 1996b). Similar results were obtained when infections of cucumber plants by two cucumoviruses were analyzed (Thompson and García-Arenal 1998). Thus, for N. tabacum and cucumber plants inoculated with these virus strains, there is no apparent restriction of virus movement between M and BS cells. Ding et al. (1992) demonstrated, with dye-coupling experiments, that the TMV 30-kDa movement protein can significantly increase the size exclusion limit of PD between $\mathrm{M}$ cells and between $\mathrm{M}$ cells and BS cells in N. tabacum, but not between BS and interior vein cells. This indicates that PD between BS cells and nonvascular cells are functionally different from those between the BS cells and interior vein cells. Thus, although previous reports have shown a lack of regulation of virus or dye entry into BS cells from $\mathrm{M}$ cells, our current results with BMV in-
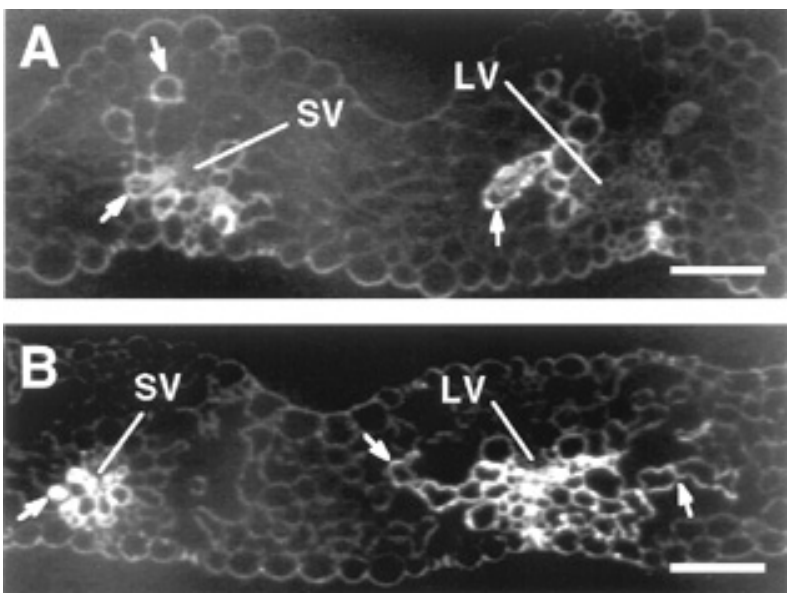

Fig. 5. Immunocytochemical detection of brome mosaic virus (BMV) capsid protein (CP) in cells of systemically infected leaf blades of Hordeum vulgare (cv. Morex) at various days post inoculation (dpi). A, Section is from a systemically infected leaf blade harvested at $8 \mathrm{dpi}$ and analyzed for BMV CP accumulation as described in Figure 1. Labeling signal appears as white specks. Arrows indicate cells displaying labeling signal. B, Section is from a systemically infected leaf blade harvested at $25 \mathrm{dpi}$ and analyzed as for the section in A. LV, large vein; SV, small vein. Bar $=80 \mu \mathrm{m}$. 
dicate that exit from BS cells to M cells or movement between $M$ cells in barley leaves may be regulated.

There are reasons to conclude that the inability of BMV to efficiently accumulate in $\mathrm{M}$ cells in barley leaves is not due to an inability of the virus to replicate in these cells. Firstly, previous reports have shown that the virus can accumulate normally in barley protoplasts that likely originate from $\mathrm{M}$ cells (Kroner et al. 1989; Loesch-Fries and Hall 1980; Okuno and Furusawa 1978a). We also determined that BMV accumulated in protoplasts incubated at $24^{\circ} \mathrm{C}$ (data not shown). Secondly,

Table 3. Numbers of infected interveinal areas categorized according to their percentage of infected, nonvascular-associated mesophyll cells

\begin{tabular}{|c|c|c|c|c|}
\hline \multirow[b]{2}{*}{ Treatment } & \multirow{2}{*}{$\begin{array}{c}\text { Areas } \\
\text { examined (no.) }\end{array}$} & \multicolumn{3}{|c|}{$\begin{array}{c}\text { Infected, nonvascular-associated } \\
\text { mesophyll cells }(\%)^{\mathbf{b}}\end{array}$} \\
\hline & & $<20 \%$ & $20-80 \%$ & $>80 \%$ \\
\hline $24 / 20^{\circ} \mathrm{C}$ & $62(37.0 \pm 5)$ & $56(90.3)$ & $5(8.1)$ & $1(1.6)$ \\
\hline $26 / 20^{\circ} \mathrm{C}$ & $63(46.0 \pm 3)$ & $55(87.3)$ & $6(9.5)$ & $2(3.2)$ \\
\hline $30^{\circ} \mathrm{C} ; 2 \mathrm{~h}$ & $66(32.6 \pm 4)$ & $53(80.3)$ & $9(13.6)$ & $4(6.1)$ \\
\hline $34^{\circ} \mathrm{C} ; 2 \mathrm{~h}$ & $44(47.0 \pm 3)$ & $1(2.3)$ & $9(20.5)$ & $34(77.3)$ \\
\hline
\end{tabular}

a Numbers in parentheses indicate mean number of nonvascularassociated mesophyll cells per interveinal area from five randomly chosen areas \pm standard errors.

${ }^{b}$ Numbers in parentheses indicate percentage of areas in this category versus total number of areas observed.
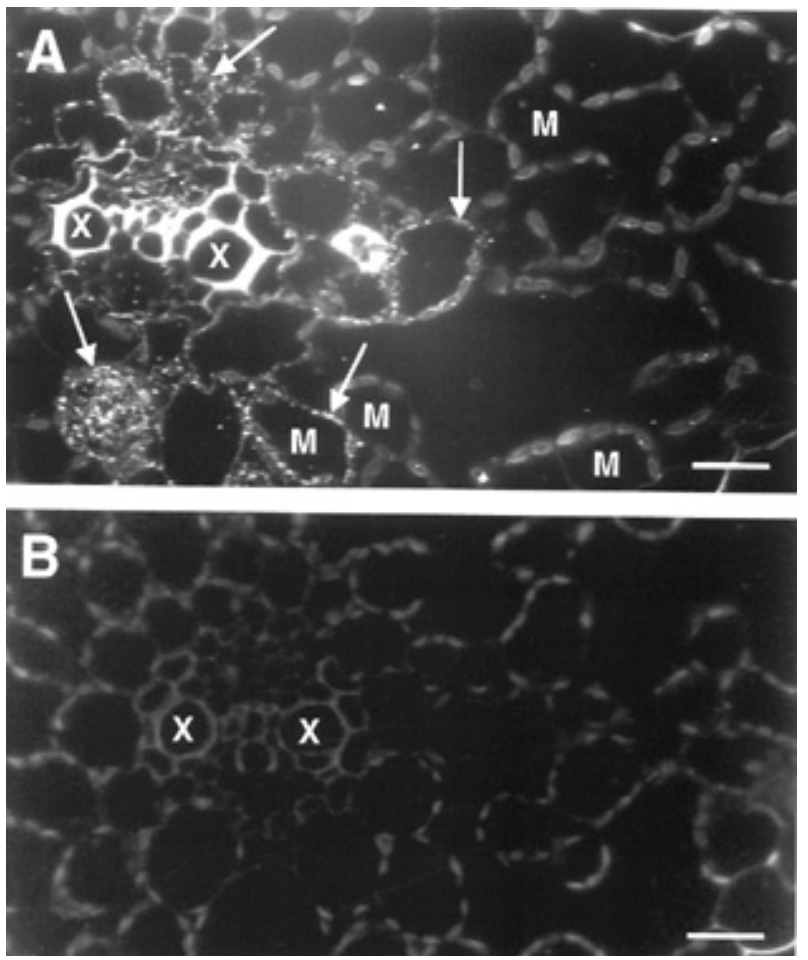

Fig. 6. Accumulation of brome mosaic virus (BMV) RNA components in cells of an inoculated leaf blade of Hordeum vulgare (cv. Morex) at 8 days post inoculation. A, Section from a large vein of a virus-inoculated leaf blade analyzed by in situ hybridization with a biotinylated-RNA probe specific for the $3^{\prime}$ untranslated region of the BMV RNA components. Section was photographed under a Nikon Microphot-FX microscope as dark field image. Labeling signal appears as white specks. B, Section from a large vein of a mock-inoculated leaf blade analyzed as for the section in A. Arrows indicate cells displaying labeling signal. Bar $=28 \mu \mathrm{m}$. some interveinal areas of systemically infected leaves of Morex grown at $24 / 20^{\circ} \mathrm{C}$ had more than $20 \%$ of the nonvascularassociated $\mathrm{M}$ cells infected (Table 3 and Fig. 5B). This suggests that if the virus can escape to the $M$ cells it can replicate. Lastly, microinjection of lucifer yellow (a symplasmic fluorescent dye) into BS cells in barley leaves resulted in the movement of the dye between BS cells but rarely into M cells (data not shown; Botha and Cross 1997; Farrar et al. 1992). This result indicates that host factor(s) exist that limit the spread of fluorescent dye between BS and M cells. Our analysis of PD between BS and M cells and between BS and MS cells indicated that the PD at these cell interfaces were similar in appearance in spite of the differential virus accumulation observed in these cell pairs (Fig. 7). In addition, it has been observed that more PD exist between BS and M cells, compared with BS and BS cells, BS and MS cells, and MS and MS cells (Evert et al. 1996). Thus, host factor(s) other than those observed under the electron microscope control BMV and dye movement from BS into M cells and between M cells.
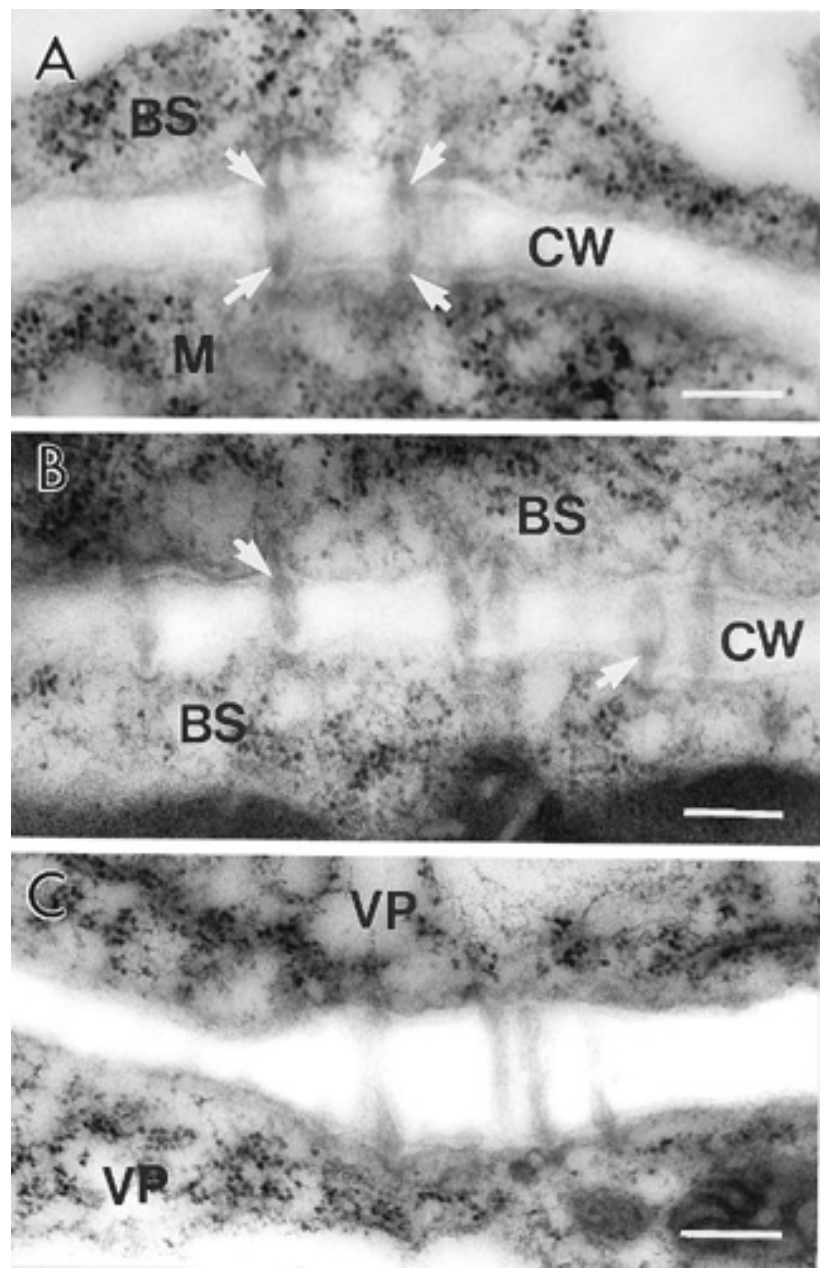

Fig. 7. Electron micrographs of plasmodesmata between different types of cells in infected barley leaves. A, Longitudinal view of plasmodesmata in a cell wall between an $\mathrm{M}$ cell and a BS cell. B, Longitudinal view of plasmodesmata in a cell wall between two BS cells. Electronopaque structures (sphincters) can be seen at the restricted neck regions (arrows). C, Longitudinal view of plasmodesmata in a cell wall between two VP cells. CW, cell wall; BS, bundle sheath cell; M, mesophyll cell; $\mathrm{VP}$, vascular parenchyma cell. Bar $=0.1 \mu \mathrm{m}$. 
Further work is required to determine the relationship of the dye movement to the virus movement, eliminate the possibility that virus replication in $\mathrm{M}$ cells of barley leaf is inhibited, and, if replication is not inhibited, what host factor(s) impede BMV movement in barley through specific PD. In regard to viral factor(s) that may be involved in BMV movement, tubular structures containing viruslike particles were observed
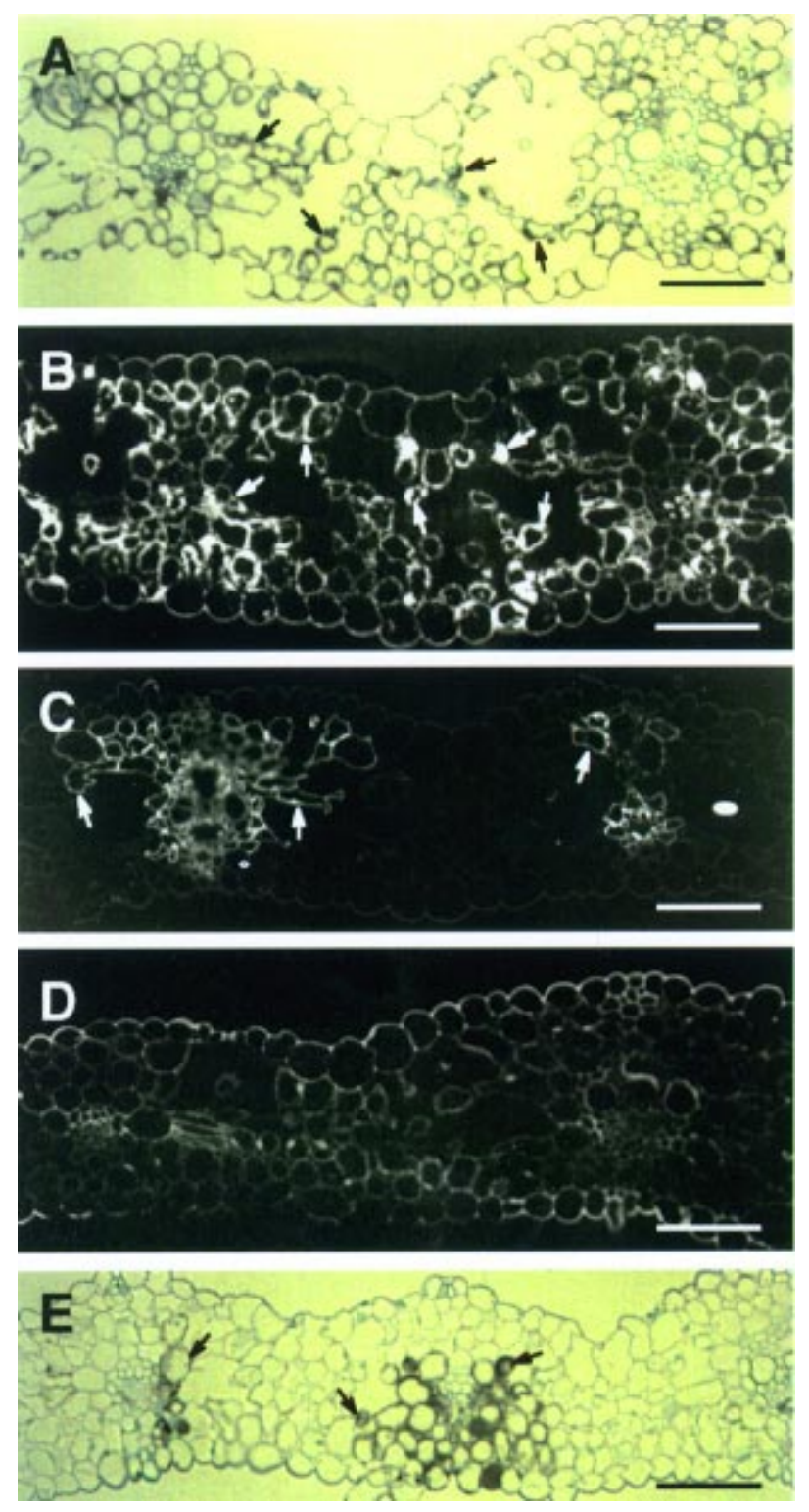

Fig. 8. Accumulation of brome mosaic virus (BMV) capsid protein (CP) and RNA components in cells of systemically infected leaf blades of Hordeum vulgare (cv. Morex) at 3 days after transient high temperature treatments. A, Section is from an infected plant treated for $2 \mathrm{~h}$ at $34^{\circ} \mathrm{C}$ and analyzed for BMV CP accumulation as described in Figure 1. Signal appears as dark brown to black specks (arrows). B, Section is from an infected plant treated for $2 \mathrm{~h}$ at $34^{\circ} \mathrm{C}$ and analyzed for BMV RNA accumulation as described in Figure 6. Signal appears as white specks (arrows). C, Section is from an infected plant treated for $2 \mathrm{~h}$ at $30^{\circ} \mathrm{C}$ and analyzed for BMV CP accumulation as described in Figure 4. Signal appears as white specks (arrows). D, Section is from a mock-inoculated leaf blade and analyzed as for the section in B. E, Section is from an infected plant grown under standard conditions (i.e., no transient high temperature) and analyzed for BMV CP accumulation. Bar $=80 \mu \mathrm{m}$. from cowpea protoplasts infected with BMV (strain M1) (Kasteel et al. 1997). In agreement with a previous report by Fujita et al. (1998), we did not observe similar tubular structures within or adjacent to PD in walls between infected cells by electron microscopy. It is possible that we did not observe this type of structure if it exists only transiently and at the front of a virus infection locus. Transient positioning of virusinduced cytoplasmic bodies on either side of a PD (i.e., in a paired position) has been observed in TMV-infected Nicotiana benthamiana (Szécsi et al. 1999).

The developmental stage of the leaf and the environment in which the host is grown may also affect the accumulation of viruses in particular cells. Lucy et al. (1996) investigated maize streak virus (a phloem-associated geminivirus) infection in maize leaves. They determined that virus accumulation in mature leaves was not limited to vascular cells, unlike what was observed in apical tissue. Hamilton and Nichols (1977) inoculated barley plants with a mixture of TMV and BMV, and treated the inoculated plants with different temperatures. They observed that the virus-inoculated plants maintained at a constant temperature of $31^{\circ} \mathrm{C}$ were systemically infected with TMV, but no systemic infection occurred in plants grown at 20 or $25^{\circ} \mathrm{C}$. In our work, we observed that even a short time treatment (i.e., $2 \mathrm{~h}$ ) at $34^{\circ} \mathrm{C}$, but not at $30^{\circ} \mathrm{C}$, allowed accumulation of BMV in almost all $\mathrm{M}$ cells in infected barley leaves (Fig. 8A and B, Table 3). The minimum amount of time at $34^{\circ} \mathrm{C}$ necessary to allow BMV accumulation in $\mathrm{M}$ cells is not known, but a transient temperature flux to this temperature in field or greenhouse conditions can occur. This temperature effect would appear to be on virus movement since it has been demonstrated that BMV replication in barley protoplasts at $24^{\circ} \mathrm{C}$ is equivalent to that observed at $34^{\circ} \mathrm{C}$ (Kroner et al. 1989). Gamalei and co-workers (1994) reported that a change of temperature can alter the endoplasmic reticulum network in vein cells and thus possibly photosynthate transport via PD between cells of the phloem-loading zone in several plant species. They suggested that this may have an effect on trafficking of macromolecules such as viruses. Further studies are required to determine the size exclusion limit of PD between different cell types in barley leaves under different temperature conditions.

In regard to vascular transport of BMV, we observed that this virus is likely to invade systemic tissues of barley before spreading into all longitudinal veins in the inoculated leaves. Our time course studies of BMV infection in barley with enzyme-linked immunosorbent assay (ELISA) have shown that BMV CP can be detected in blade tissue of the inoculated leaves by 2 dpi and sheath tissue proximal to the stem by 3 dpi (Table 1). Experiments with a leaf detachment technique have demonstrated that BMV is able to cause systemic infection in barley even when the inoculated leaves of the plants were detached at 2.5 dpi (data not shown). Results of immunocytochemistry and in situ hybridization show, however, that at 3 dpi when rapid phloem-dependent movement of the virus is occurring, less than $30 \%$ (12 out of 45 ) of the longitudinal veins in the inoculated leaves analyzed had accumulated the virus (Table 2). These results indicate that vascular movement of BMV is more rapid to sink tissue than to all longitudinal veins within the inoculated source leaf. Whether this virus accumulation pattern is due to photoassimilate flow patterns in plant or due to a virus-specific inhibition of movement between longitudinal veins requires study. 


\section{MATERIALS AND METHODS}

\section{Plants and virus.}

Hordeum vulgare L. cvs. Morex (Old Seed Co., Madison, WI), Post 40, and Tam Bar401 (both from Eugene G. Krenzer, Oklahoma State University, Stillwater) were used in this study. Seeds were planted in an artificial soil mix (Metro-Mix 350; Scotts-Sierra Horticultural Products Company, Marysville, $\mathrm{OH}$ ) in $16.51-\mathrm{cm}$ pots. At 2 days post germination, the seedlings (five plants per pot) were transferred into a growth chamber (model RE-16; Percival Scientific, Boone, IA) with a $24^{\circ} \mathrm{C} / 16 \mathrm{~h}$ light and $20^{\circ} \mathrm{C} / 8 \mathrm{~h}$ dark cycle (standard condition). The photosynthetic photon flux density (400 to $700 \mathrm{~nm}$ ) was maintained at $150 \mu \mathrm{mol} \mathrm{s} \mathrm{s}^{-1} \mathrm{~m}^{-2}$. Purified Russian strain of BMV was obtained from John Sherwood (University of Georgia, Athens; Sherwood and Fulton 1982) and maintained thereafter on $H$. vulgare cv. Morex.

\section{BMV antiserum and biotinylated RNA probe.}

Polyclonal antiserum against BMV was produced by injecting BMV virion, purified as described (Lane 1981), intramuscularly into a rabbit. The biotinylated-RNA probe specific for the conserved 3' untranslated region of the BMV genomic RNAs was prepared from the plasmid pGEM3-B3-3 (Nagy and Bujarski 1992) with biotin-14-CTP (Life Technologies, Gaithersburg, MD) as described (Ding et al. 1996a).

\section{Virus inoculations.}

At 2 weeks post planting, the third leaf of each plant was dusted with Carborundum and hand inoculated with $25 \mu \mathrm{l}$ of virus inoculum. The virus inoculum was prepared by grinding young Morex leaves, systemically infected with BMV, in a $0.05 \mathrm{M}$ phosphate buffer, pH 6.0 (1:5, wt/vol). The inoculated leaves were rinsed immediately with distilled water and the plants were grown either under the standard conditions as indicated above or at $26^{\circ} \mathrm{C} / 16 \mathrm{~h}$ light and $20^{\circ} \mathrm{C} / 8 \mathrm{~h}$ dark growth chambers. At various dpi, the blade and sheath tissue of each inoculated leaf were harvested and analyzed individually for virus infection. Four to five plants were used for each treatment, and each treatment was repeated once. Post 40 and Tam Bar401 were grown under the standard conditions, sampled at $8 \mathrm{dpi}$, and analyzed by immunocytochemistry and light microscopy. To investigate the accumulation of BMV in systemically infected leaves, Morex plants were inoculated with the virus as described above. Uninoculated leaves showing virus symptoms were sampled at 8 or 25 dpi and analyzed. Two phosphate buffer-inoculated (mock-inoculated) plants were used as healthy controls in each experiment.

\section{ELISA.}

Individual blade tissues ( $5 \mathrm{~cm}$ long, proximal to the sheath) and sheath tissues ( $4 \mathrm{~cm}$ long, proximal to the stem) from the inoculated leaves were harvested and ground in the phosphate buffer used for virus inoculations ( $1 \mathrm{~g} \mathrm{fw}$ : $5 \mathrm{ml}$ of buffer). Protein concentrations in each extract were determined with the Bio-Rad Protein Assay Kit (Bio-Rad Laboratories, Life Science Group/Molecular Bioscience Group, Hercules, CA). ELISAs were conducted essentially as described by Barbara and Clark (1982). Specifically, ELISA plates coated with the $\mathrm{F}\left(\mathrm{ab}^{\prime}\right) 2$ fragments from the BMV antibody $(1: 8,000$, vol/vol, in coating buffer) were incubated overnight with extracts at $4^{\circ} \mathrm{C}$. The plates were washed and then incubated for $3 \mathrm{~h}$ at $37^{\circ} \mathrm{C}$ with the antiserum $(1: 15,000, \mathrm{vol} / \mathrm{vol}$, in ELISA buffer $)$, washed and then incubated for $3 \mathrm{~h}$ at $37^{\circ} \mathrm{C}$ with goat antirabbit IgG alkaline phosphatase conjugate (Promega, Madison, WI; 1:7,500, vol/vol, in ELISA buffer). The F(ab')2 fragment of the BMV antibody was prepared as described by Barbara and Clark (1982). For leaf blade and sheath samples, extracts containing approximately 5 and $2 \mu \mathrm{g}$ of total protein, respectively, were loaded into the wells.

\section{Tissue fixation and embedding.}

Tissues $(6 \times 3 \mathrm{~mm})$ were sampled from the basal portion of the inoculated and the central portion of the uninoculated, systemically infected leaf blades at various dpi. They were microwaved for $3 \mathrm{~s}$ in 3\% paraformaldehyde and 1\% glutaraldehyde in $0.1 \mathrm{M}$ sodium cacodylate buffer, $\mathrm{pH} 7.4$, and then in the same fixation solution for $4 \mathrm{~h}$ at room temperature (RT). After three washes in the sodium cacodylate buffer containing $2 \%$ sucrose, tissues were dehydrated in a graded ethanol solution series and embedded in LR White resin as described (Ding et al. 1995). For ultrastructural analysis, tissues were post-fixed for $1 \mathrm{~h}$ in a $1 \%$ osmium tetroxide solution at RT.

\section{Immunocytochemistry and light microscopy.}

Sections $(2 \mu \mathrm{m}$ thick) were cut from embedded tissues and probed with an antiserum against BMV CP by a double-sided labeling technique (Ding et al. 1996a). The BMV antiserum and goat anti-rabbit IgG gold $(5 \mathrm{~nm})$ conjugate were used, respectively, at 1:10,000 and 1:200 (vol/vol) in a $2 \%$ bovine serum albumin (BSA) solution. Silver enhancement was done in the dark for 15 to $20 \mathrm{~min}$ at RT. Sections from infected leaf tissues probed with preimmune serum, or sections from healthy leaf tissues probed with BMV antiserum, were used as controls. Sections were lightly stained with $0.01 \%$ toluidine blue and then examined and photographed under a Nikon Microphot-FX microscope as dark field or Nomarski images.

\section{In situ hybridization and light microscopy.}

Sections $(2 \mu \mathrm{m}$ thick) were cut from the inoculated and systemically infected leaf blade tissues harvested at 8 or 25 dpi. The sections were probed with the biotinylated-RNA probe ( $2 \mu \mathrm{g}$ of RNA probe per $\mathrm{ml}$ of hybridization solution, 20 $\mu \mathrm{l}$ per well) by a double-sided labeling technique (Ding et al. 1996a). Streptavidin-gold (5 nm; BioCell Research Laboratories, Cardiff, UK) conjugate was used at 1:200 (vol/vol) in a $2 \%$ BSA solution and silver enhancement was done in the dark for $8 \mathrm{~min}$ at RT. The sections were examined and photographed under a Nikon Microphot-FX microscope as dark field images.

\section{Immunocytochemistry and electron microscopy.}

Thin sections (100 nm thick) were cut from embedded leaf tissues and mounted on formvar/carbon coated slot nickel grids. The sections were incubated with BMV CP antiserum $(1: 15,000, \mathrm{vol} / \mathrm{vol}$, in a $2 \%$ BSA solution) followed by goat anti-rabbit IgG gold $(20 \mathrm{~nm})$ conjugate $(1: 200$, vol/vol) as described (Ding et al. 1995). The labeled sections were examined and photographed under a Zeiss 10A electron microscope operating at $80 \mathrm{kv}$ or Jeol 2000 electron microscope operating at $100 \mathrm{kv}$. Sections from healthy tissues incubated with BMV $\mathrm{CP}$ antiserum were used as negative controls. To investigate 
the structure of PD at various cell interfaces, sections were prepared from the osmium fixed tissues and examined after poststaining in $2 \%$ uranyl acetate and Reynold's lead citrate as described (Ding et al. 1995).

\section{Temperature shift experiment.}

Barley plants (cv. Morex) were grown in a growth chamber and inoculated as described previously. At $5 \mathrm{dpi}$, the inoculated plants were placed in a growth chamber at $34^{\circ} \mathrm{C}$ for 2,4 , or $8 \mathrm{~h}$ or at $30^{\circ} \mathrm{C}$ for $2 \mathrm{~h}$. These plants were then placed back in a growth chamber set at $24 / 20^{\circ} \mathrm{C}$ (i.e., standard conditions). Four to five plants were used for each treatment and the experiment was repeated once. At 3 days after the high temperature treatment (or $8 \mathrm{dpi}$ ), the fourth leaf (the leaf above the inoculated leaf and showing systemic virus symptoms) of each inoculated plant was sampled and analyzed by immunocytochemistry and in situ hybridization as described above. In each experiment, two mock-inoculated plants treated at $34^{\circ} \mathrm{C}$ for $4 \mathrm{~h}$ or $30^{\circ} \mathrm{C}$ for $2 \mathrm{~h}$ and two BMV-inoculated plants grown only under standard conditions were used as controls.

\section{ACKNOWLEDGMENTS}

We acknowledge John Sherwood for supplying purified BMV, Eugene Krenzer for supplying barley seeds, Scott Russell and Greg Strout for access to the electron microscope facility at the University of Oklahoma, and Aart van Bel for use of the microinjection facility at the Justus-Liebig University, Giessen, Germany. We also thank William Schneider and Christopher Steele for their critical comments during preparation of the manuscript, Christy Boydston for technical assistance, Cuc Ly for preparing figures, and Allyson Wilkins for typing the manuscript.

\section{LITERATURE CITED}

Ahlquist, P., Luckow, P., and Kaesberg, P. 1981. Complete nucleotide sequence of brome mosaic virus RNA3. J. Mol. Biol. 153:23-38.

Allison, R. F., Janda, A., and Ahlquist, P. 1988. Infectious in vitro transcripts from cowpea chlorotic mottle virus cDNA clones and exchange of individual RNA components with brome mosaic virus. J. Virol. 62: 3581-3588.

Barbara, D. J., and Clark, M. F. 1982. A simple indirect ELISA using $\mathrm{F}\left(\mathrm{ab}^{\prime}\right) 2$ fragments of immunoglobulin. J. Gen. Virol. 58:315-322.

Botha, C. E. J., and Cross, R. H. M. 1997. Plasmodesmatal frequency in relation to short-distance transport and phloem loading in leaves of barley (Hordeum vulgare). Phloem is not loaded directly from the symplast. Physiol. Plant. 99:355-362.

Dannenhoffer, J. M., Ebert, W., and Evert, R. F. 1990. Leaf vasculature in barley, Hordeum vulgare (Poaceae). Am. J. Bot. 77:636-652.

Dasgupta, R., and Kaesberg, P. 1982. Complete nucleotide sequences of the coat protein messenger RNAs of brome mosaic virus and cowpea chlorotic mottle virus. Nucleic Acids Res. 10:703-713.

De Jong, W., Chu, A., and Ahlquist, P. 1995. Coding changes in the 3a cell-to-cell movement gene can extend the host range of brome mosaic virus systemic infection. Virology 214:464-474.

Ding, B., Haudenshield, J. S., Hull, R. J., Wolf, S., Beachy, R. N., and Lucas, W. J. 1992. Secondary plasmodesmata are specific sites of localization of the tobacco mosaic virus movement protein in transgenic tobacco plants. Plant Cell 4:915-928.

Ding, X. S., Carter, S. A., and Nelson, R. S. 1996a. Enhanced cytochemical detection of viral proteins and RNAs using double-sided labeling and light microscopy. BioTechniques 20:111-115.

Ding, X. S., Shintaku, M. H., Arnold, S. A., and Nelson, R. S. 1995. Accumulation of mild and severe strains of tobacco mosaic virus in minor veins of tobacco. Mol. Plant-Microbe Interact. 8:32-40.

Ding, X. S., Shintaku, M. H., Carter, S. A., and Nelson, R. S. 1996b. Invasion of minor veins of tobacco leaves inoculated with tobacco mosaic virus mutants defective in phloem-dependent movement. Proc.
Natl. Acad. Sci. USA 93:11155-11160

Evert, R. F., Russin, W. A., and Botha, C. E. J. 1996. Distribution and frequency of plasmodesmata in relation to photoassimilate pathways and phloem loading in the barley leaf. Planta 198:572-579.

Farrar, J., van der Schoot, C., Drent, P., and van Bel, A. 1992. Symplastic transport of Lucifer Yellow in mature leaf blades of barley: Potential mesophyll-to-sieve-tube transfer. New Phytol. 120:191196.

Flasinski, S., Dzianott, A., Pratt, S., and Bujarski, J. J. 1995. Mutational analysis of the coat protein gene of brome mosaic virus: Effects on replication and movement in barley and in Chenopodium hybridum. Mol. Plant-Microbe Interact. 8:23-31.

Ford, R. E., Fagbenle, H., and Stoner, W. N. 1970. New hosts and serological identity of bromegrass mosaic virus from South Dakota. Plant Dis. Rep. 54:191-195.

Fujita, M., Mise, K., Kajiura, Y., Dohi, K., and Furusawa, I. 1998. Nucleic acid-binding properties and subcellular localization of the $3 \mathrm{a}$ protein of brome mosaic bromovirus. J. Gen. Virol. 79:1273-1280.

Gamalei, Y. V., van Bel, A. J. E., Pakhomova, M. V., and Sjutkina, A. V. 1994. Effects of temperature on the conformation of the endoplasmic reticulum and on starch accumulation in leaves with the symplasmic minor-vein configuration. Planta 194:443-453.

Hamilton, R. I., and Nichols, C. 1977. The influence of bromegrass mosaic virus on the replication of tobacco mosaic virus in Hordeum vulgare. Phytopathology 67:484-489.

Kaido, M., Mori, M., Mise, K., Okumo, T., and Furusawa, I. 1995. Inhibition of brome mosaic virus (BMV) amplification in protoplasts from transgenic tobacco plants expressing replicable BMV RNAs. J. Gen. Virol. 76:2827-2833.

Kasteel, D. T. J., van der Wel, N. N., Jansen, K. A. J., Goldbach, R. W. and van Lent, J. W. M. 1997. Tubule-forming capacity of the movement proteins in alfalfa mosaic virus and brome mosaic virus. J. Gen. Virol. 78:2089-2093.

Kiberstis, P. A., Loesch-Fries, L. S., and Hall, T. C. 1981. Viral protein synthesis in barley protoplasts inoculated with native and fractionated brome mosaic virus RNA. Virology 112:804-808.

Kroner, P., Richards, D., Traynor, P., and Ahlquist, P. 1989. Defined mutations in a small region of the brome mosaic virus 2 a gene cause diverse temperature-sensitive RNA replication phenotypes. J. Virol. 63:5302-5309.

Kroner, P. A., Young, B. M., and Ahlquist, P. 1990. Analysis of the role of brome mosaic virus 1a protein domains in RNA replication, using linker insertion mutagenesis. J. Virol. 64:6110-6120.

Lane, L. C. 1981. Bromoviruses. Pages 333-375 in: Handbook of Plant Virus Infections Comparative Diagnosis. E. Kurstak, ed. Elsevier/ North-Holland Biomedical Press, Amsterdam.

Loesch-Fries, L. S., and Hall, T. C. 1980. Synthesis, accumulation and encapsidation of individual brome mosaic virus RNA components in barley protoplasts. J. Gen. Virol. 47:323-332.

Lucy, A. P., Boulton, M. I., Davies, J. W., and Maule, A. J. 1996. Tissue specificity of Zea mays infection by maize streak virus. Mol. PlantMicrobe Interact. 9:22-31.

McKinney, H. H. 1953. New evidence on virus diseases in barley. Plant Dis. Rep. 37:292-295.

Mise, K., and Ahlquist, P. 1995. Host-specificity restriction by bromovirus cell-to-cell movement protein occurs after initial cell-to-cell spread of infection in nonhost plants. Virology 206:276-286.

Mise, K., Allison, R. F., Janda, M., and Ahlquist, P. 1993. Bromovirus movement protein genes play a crucial role in host specificity. J. Gen. Virol. 67:2815-2823.

Nagy, P. D., and Bujarski, J. J. 1992. Genetic recombination in brome mosaic virus: Effect of sequence and replication of RNA on accumulation of recombinants. J. Virol. 66:6824-6828.

Nelson, R. S., and van Bel, A. J. E. 1998. The mystery of virus trafficking into, through and out of the vascular tissue. Prog. Bot. 59:476-533.

Okuno, T., and Furusawa, I. 1978a. Modes of infection of barley protoplasts with brome mosaic virus. J. Gen. Virol. 38:409-418.

Okuno, T., and Furusawa, I. 1978b. Factors influencing the infection of barley mesophyll protoplasts with brome mosaic virus RNA. J. Gen. Virol. 41:63-75.

Osman, F., Grantham, G. L., and Rao, A. L. N. 1997. Molecular studies on bromovirus capsid protein. IV. Coat protein exchanges between brome mosaic and cowpea chlorotic mottle viruses exhibit neutral effects in heterologous hosts. Virology 238:452-459. 
Paliwal, Y. C. 1970. Electron microscopy of bromegrass mosaic virus in infected leaves. J. Ultrastruct. Res. 30:491-502.

Quadt, R., and Jaspars, E. M. J. 1990. Purification and characterization of brome mosaic virus RNA-dependent RNA polymerase. Virology 178:189-194.

Rao, A. L. N., and Grantham, G. L. 1996. Molecular studies on bromovirus capsid protein. II. Functional analysis of the amino-terminal arginine-rich motif and its role in encapsidation, movement, and pathology. Virology 226:294-305.

Robinson-Beers, K., and Evert, R. F. 1991. Fine structure of plasmodesmata in mature leaves of sugarcane. Planta 184:307-318.

Sherwood, J. L., and Fulton, R. W. 1982. The specific involvement of coat protein in tobacco mosaic virus cross protection. Virology 119 $150-158$.

Sullivan, M. L., and Ahlquist, P. 1997. cis-Acting signals in bromovirus
RNA replication and gene expression: Networking with viral proteins and host factors. Sem. Virol. 8:221-230.

Szécsi, J., Ding, X. S., Lim, C. O., Bendahmane, M., Cho, M. J., Nelson, R. S., and Beachy, R. N. 1999. Development of tobacco mosaic virus infection sites in Nicotiana benthamiana. Mol. Plant-Microbe Interact. 12:143-152.

Thompson, J. R., and García-Arenal, F. 1998. The bundle sheath-phloem interface of Cucumis sativus is a boundary to systemic infection by tomato aspermy virus. Mol. Plant-Microbe Interact. 11:109-114.

Traynor, P., Young, B. M., and Ahlquist, P. 1991. Deletion analysis of brome mosaic virus 2a protein: Effects on RNA replication and systemic spread. J. Virol. 65:2807-2815.

Trivett, C. L., and Evert, R. F. 1998. Ontogeny of the vascular bundles and contiguous tissues in the barley leaf blade. Int. J. Plant Sci. 159:716-723 